\section{Prevalence and temporal distribution of surgical diseases in goats (Capra hircus) in Mymensingh district of Bangladesh}

\section{ABSTRACT}

Surgical diseases are common in goats and exert serious negative effects on animal's growth, productivity, and survivability leading to huge economic loss. This study was aimed at determining the prevalence of different surgical diseases of goats and to elucidate the seasonal impact leading to temporal distribution of these diseases in Trishal, Muktagacha and Fulbaria of Mymensingh, Bangladesh between the years 2009 to 2019. A total of 3744 goats were documented in all three Upazila. The overall prevalence was found to be $34.18 \%$ (1280/3744) in Fulbaria, 32.69\% (1224/3744) in Muktagacha, 33.11\% (1240/3744) in Trishal. The prevalence of different surgical affections in Fulbaria included: wounds $30.54 \%$, gid $23.28 \%$, urolithiasis $16.09 \%$, bloat $9.06 \%$, fracture $8.99 \%$, lymphadenitis $6.48 \%$, tumor $4.06 \%$ and gangrenous mastitis $0.94 \%$; in Muktagacha these were wounds $30.83 \%$, gid $23.08 \%$, urolithiasis $19.98 \%$, bloat $9.89 \%$, fracture $9.06 \%$, lymphadenitis $6.59 \%$, tumor $3.70 \%$ and gangrenous mastitis $0.75 \%$; in Trishal these were wounds $28.28 \%$, gid $23.60 \%$, urolithiasis $17.20 \%$, bloat $9.12 \%$, fracture $8.96 \%$, lymphadenitis $6.88 \%$, tumor $3.76 \%$ and gangrenous mastitis $0.80 \%$. There was a somewhat similar temporal distribution pattern of the diseases in the study area. The study revealed that rainfall, relative humidity, and ambient temperature have a distinct influence on the occurrence and distribution of various surgical diseases and disorders. Prompt surgical intervention is recommended as most of the diseases are curable, and this will reduce the economic loss of the farmers.

Keywords: Surgical diseases, prevalence, temporal distribution, goats, Mymensingh.

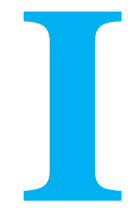

\section{NTRODUCTION}

Livestock is catalytic in helping rural households meet their livelihood goals. First, by providing access to food, continued good health, and labour, they enhance human capital to pursue activities. Second, they create social capital, reinforcing the cultural diversity and heritage of different ethnic groups and people. Third, they add to the natural capital stock that provides the goods and services required to maintain and enhance living conditions. Fourth, they expand physical resources, supplying households with transportation, draught power, and renewable energy to sustain and boost their productivity. Fifth, they increase family financial resources, provide an investment mechanism, and act as liquid assets, or as credit collateral, to protect livelihood goals. Sixth, they serve as a significant shield against outside shocks (Abed and Acosta, 2018). Given the sector's projected rapid growth and the empirical observation that many poor people's livelihoods are dependent on livestock, the contribution of the sector to poverty reduction has been highly anticipated (Islam et al., 2020).

\section{How to cite this article}

Islam, M.A., Akter, M.A., Alam, M.M. (2020). Prevalence and temporal distribution of surgical diseases in goats (Capra hircus) in Mymensingh district of Bangladesh. Journal of Advances in VetBio Science and Techniques. 5(2): 72-80. https://doi.org/10.31797/vetbio. 753673
Research Article

Md. Ariful ISLAM ${ }^{1 a}$

Mst. Antora AKTER ${ }^{1 b}$

Md. Mahmudul ALAM ${ }^{1 \mathrm{c}}$

${ }^{1}$ Department of Surgery and Obstetrics, Faculty of Veterinary Science, Bangladesh Agricultural University, Mymensingh 2202, BANGLADESH

ORCID-

a 0000-0002-2795-6614

b 0000-0002-5907-988X

c 0000-0002-3464-4125

Correspondence Md. Mahmudul Alam mahmud.dso@bau.edu.bd Article info

Submission: 09-06-2020

Accepted: 28-08-2020

Online First: 31-08-2020

e-ISSN: 2548-1150

doi prefix: $10.31797 /$ vetbio - http://dergipark.org.tr/vetbio

This work is licensed under a Creative Commons Attribution 4.0 International License (c) (1) 
Bangladesh is blessed with abundant livestock resources, and comprised of 24.238 million cattle, 1.486 million buffalo, 26.267 million goats, 3.537 million sheep (DLS, 2019). Goat is, thus, an integral component of the agricultural economy of Bangladesh performing multifarious functions such as provisions of food, nutrition, income, and savings (Talukdar et al., 2005). This economic importance is primarily associated with their small size, as it favors low investment, small risk of loss, and their high reproductive efficiency (Omoike, 2006). The benefits obtained from these species, however, are well below the predicted quantity and quality mainly due to low productivity caused by infectious, metabolic, and surgical diseases (Rassel et al., 2020).

Prevalence and intensity of pathogenic infections or surgical disorders are often seasonal, and this could be linked to changes in the host immunity or increase in the preponderance of either the pathogen or vector or both (Nelson et al., 2002; Alam et al., 2005a). Goats often suffer from a wide variety of surgical affections; e.g. gid disease, wound, urolithiasis, lymphadenitis, subcutaneous cyst, fracture, myiasis, bloat, and so on and all these are curable if surgical intervention is performed at an appropriate time (Alam et al., 2005b; Hossain et al., 2014; Miah et al., 2017). The knowledge of the pattern of disease occurrence is essential as it suggests a period of likely occur.

Considering the importance of goat to the economies of Bangladesh, and the negative implications of surgical affections on its productivity and reproductivity, this study is aimed to determine the prevalence of surgical diseases and disorders and to deduce the effect of seasonal changes on the prevalence of these diseases in Fulbaria, Muktagacha and Trishal, Mymensingh district of Bangladesh.

\section{MATERIALS and METHODS}

\section{Study area}

A cross-sectional study was conducted to assess the prevalence of surgical affections in Fulbaria, Muktagacha, and Trishal Upazilas, which are located at the South-west part of Mymensingh, one of the oldest city of Bangladesh seen in Figure 1.

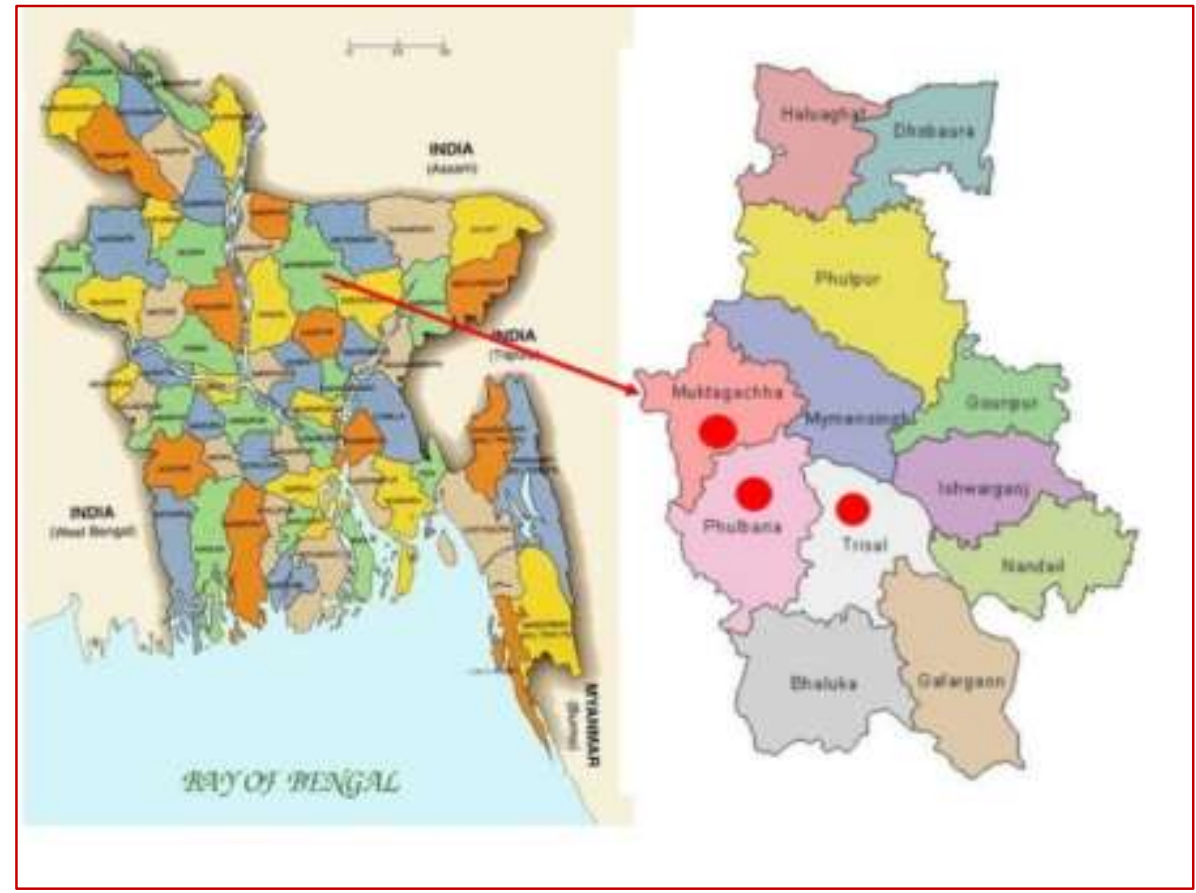

Figure 1. Study area highlighting South-West part of Mymensingh district. 


\section{Retrospective data collection}

We have collected retrospective data from the clinical datasheet and consulting the veterinary Surgeon of each hospital. The history and clinical examinations were performed by the Veterinary Surgeon of each hospital and marked in the clinical datasheet. Briefly, the history of each case was taken from the animal's owner. The data regarding age, sex, species, breed, time of onset of the disease, previous medication, and health status were also recorded. Clinical signs, including any changes in the animal behavior, appetite, nature of excretion and secretions, locomotion disorders, swellings, and expressions of pain and other alignments were recorded in the same way. The affected parts and lesions were manipulated to detect their nature, consistency, and tenderness. Physical examination, including pulse and respiration rates, body temperature, and lymph nodes, was performed to determine the health status of animals.

\section{Study designs and sampling strategy}

A total of 3744 surgically affected goats were registered in three Upazila Veterinary Hospitals. Because we were intended to study the seasonal distribution of the surgical diseases, we emphasized the collection of data targeting season of the year. We categorized the season into FOUR based on the climatic feature of the country round the year: summer (April to June), rainy (July to August), autumn (September to October), winter (November to March). The distribution of surgical disorders in the season was evaluated by observing the date of the cases recorded.

\section{Ethical scope}

This animal work was carried out in accordance with the guidelines and approval of the Animal Ethics and Experimentation Committee (AEEC) of the Department of Surgery and Obstetrics, Bangladesh Agricultural University,
Mymensingh (Permission

Number:

AEEC/DSO-BAU/01/2017).

\section{Data management and analysis}

A structured data handling format was prepared, and every vital information (variable) associated with the objective of the investigation was adequately gathered and recorded. After collection, data were inserted in the Microsoft Excel spreadsheet, and percentages of various surgical affections in different Upazilas were calculated. The prevalence of surgical attachments was estimated as the specific cases of surgical affections divided by the total number of infected animals $\times 100$.

\section{RESULTS}

In this study, we found the maximum surgical affections in goats at Upazila Veterinary Hospital, Fulbaria followed by those in Trishal and Muktagacha seen in Figure 2A. In all three Upazila, the most prevalent surgical affection was various sorts of the wound, and the least was gangrenous mastitis seen in Figure 2B.

The prevalence of surgical affection in goats in Fulbaria Upazila is presented in Table 1. As illustrated in Table 1, the wound was the most prevalent $(30.54 \%)$ caprine surgical disease in Fulbaria Upazila. The study revealed that the highest prevalence of wounds, $40.67 \%$ was in the rainy season, followed by $28.55 \%$ in summer, $15.85 \%$ in autumn, and least prevalence was observed, $14.84 \%$ in the winter season.

In this study, 305 animals representing $23.82 \%$ of the total examined animals were diagnosed as gid disease. When the hospital record were analyzed based on season, the frequency of gid was peak in rainy season, $41.96 \%(n=128)$, followed by $23.27 \%(n=71)$ in autumn, $20.00 \%(\mathrm{n}=61)$ in summer and $14.75 \%(n=45)$ in winter 


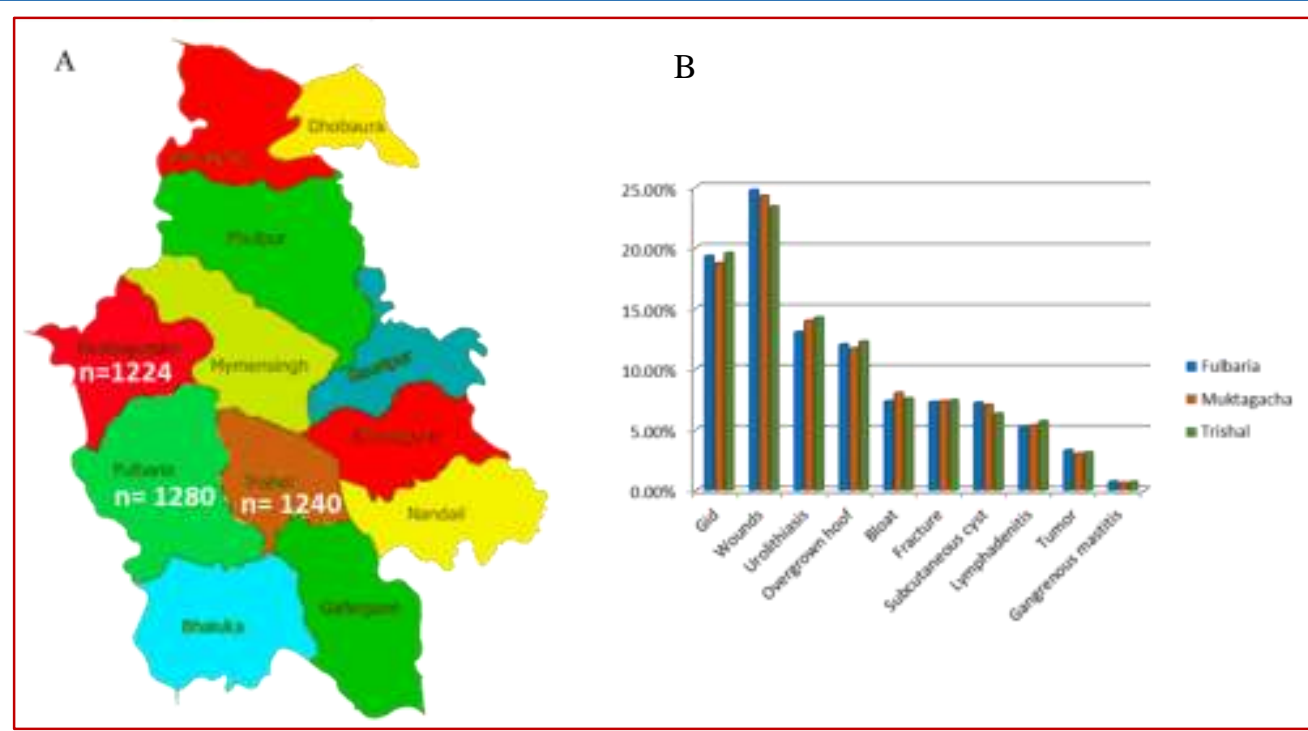

Figure 2. Documented cases (A) and comparative analysis of the prevalence of individual surgical affection (B) in three Upazila of Mymensingh.

Analysis of the data revealed $116(9.06 \%)$ cases of bloat, which were mostly observed in autumn season $(47.41 \%, \mathrm{n}=55)$ followed by rainy $(33.62 \%)$, summer $(10.34 \%)$ and winter season $(8.62 \%)$. Fracture comprised one of the major surgical cases in goats having serious impinge on small ruminants, causing lameness. Out of 1280 clinical cases, 115 (8.99\%) cases were diagnosed with different types of fractures with severe injury. Prevalence was mostly recorded in rainy season $40.00 \%$, followed by summer $(33.91 \%)$, autumn $(15.65 \%)$, and winter season $(10.43 \%)$, as presented in Table 1.
In this study, lymphadenitis was recorded at $6.48 \%(n=83)$ of total animals examined. Analysis of 83 clinical cases of lymphadenitis in goats revealed that the case was most prevalent in the summer season $(44.57 \%)$ followed by $26.50 \%$ in winter, $16.86 \%(n=14)$ in rainy and $12.04 \%(n=10)$ in the autumn season. In this study period, $12(0.94 \%)$ cases were diagnosed with gangrenous mastitis. Most of the goats were affected during the summer season $(33.34 \%, \mathrm{n}=4)$ than all other seasons. Other surgical affection documented in goats at Upazila Veterinary Hospital, Fulbaria, was a tumor $(4.06 \%)$ that mostly observed in the summer season. The seasonal prevalence of these affections was highlighted in Table 1.

Table 1. Prevalence and temporal distribution of surgical affections in goats at the Upazila Veterinary Hospital, Fulbaria $(n=1280)$

\begin{tabular}{|lccccc|}
\multicolumn{1}{c}{$\begin{array}{c}\text { Surgical } \\
\text { affections }\end{array}$} & $\begin{array}{c}\text { Number and prevalence of } \\
\text { individual case }\end{array}$ & Summer & Rainy & Autumn & Winter \\
\hline Wounds & $391(30.54 \%)$ & $112(28.65 \%)$ & $159(40.67 \%)$ & $62(15.85 \%)$ & $58(14.84 \%)$ \\
\hline Gid & $305(23.82 \%)$ & $61(20 \%)$ & $128(41.96 \%)$ & $71(23.27 \%)$ & $45(14.75 \%)$ \\
\hline Urolithiasis & $206(16.09 \%)$ & $29(14.07 \%)$ & $60(29.12 \%)$ & $42(20.38 \%)$ & $75(36.40 \%)$ \\
\hline Bloat & $116(9.06 \%)$ & $12(10.34 \%)$ & $39(33.62 \%)$ & $55(47.41 \%)$ & $10(8.62 \%)$ \\
\hline Fracture & $115(8.99 \%)$ & $39(33.91 \%)$ & $46(40.00 \%)$ & $18(15.65 \%)$ & $12(10.43 \%)$ \\
\hline Lymphadenitis & $83(6.48 \%)$ & $37(44.57 \%)$ & $14(16.86 \%)$ & $10(12.04 \%)$ & $22(26.50 \%)$ \\
\hline Tumor & $52(4.06 \%)$ & $21(40.38 \%)$ & $17(32.69 \%)$ & $5(9.61 \%)$ & $9(17.30 \%)$ \\
\hline $\begin{array}{l}\text { Gangrenous } \\
\text { mastitis }\end{array}$ & $12(0.94 \%)$ & $4(33.34 \%)$ & $3(25.00 \%)$ & $2(16.67 \%)$ & $3(25.00 \%)$ \\
\hline Total & $\mathbf{1 2 8 0}$ & $\mathbf{3 1 5}(\mathbf{2 4 . 6 0 \% )}$ & $\mathbf{4 6 6 ( 3 6 . 4 0 \% )}$ & $\mathbf{2 6 5}(\mathbf{2 0 . 7 0 \% )}$ & $\mathbf{2 3 4 ( 1 8 . 2 8 \% )}$ \\
\hline
\end{tabular}


We retrieved caprine surgical affections in Muktagacha from Upazila Veterinary hospital and found 1224 animals affected by various surgical diseases. Analysis of the cases in this area revealed that wounds were most prevalent in this region, $30.83 \%(n=374)$, as presented in Table 2. We have found an influence of season on the occurrence of wounds similar to Fulbaria Upazila. Here, the prevalence of wound was higher, $39.30 \% \quad(n=147)$ in rainy season followed by in summer $(29.94 \%, \mathrm{n}=112)$, autumn $(16.31 \%, \mathrm{n}=61)$ in and the least frequency was recorded in winter season $(14.43 \%, \mathrm{n}=54)$.

In this study, gid was recorded as $23.08 \%$ $(n=280 / 1224)$ among the surgical cases in Muktagacha. We have noticed a seasonal variation in the occurrence of gid, similar to Fulbaria in this region as well. Of the 280 goats diagnosed as gid, $40.00 \% \quad(n=112)$ were documented in rainy season, $24.28 \%(n=68)$ in autumn, $19.28 \%(\mathrm{n}=54)$ in summer and finally $16.42 \%(n=46)$ of wounds were encountered in winter. The detailed results have been shown in Table 2.

Out of 1224 cases registered at Muktagacha Veterinary Hospital, 19.98\% (206) were found positive for urolithiasis. In small ruminants, urinary retention due to urolithiasis is a multifactorial disease where seasonal variation reflects the occurrence of this urinary disorder. Analysis of the 206 clinical cases of urolithiasis in Muktagacha revealed that occurrence was the peak in winter $(37.86 \%, \mathrm{n}=78)$ followed by in rainy $(30.09 \%)$, in autumn $(18.93 \%)$ and the minimum prevalence was registered in summer season $(13.10 \%, \mathrm{n}=27)$.

In this work, $120(9.89 \%)$ cases were exhibited as bloat, which was most prevalent during the autumn season $(43.33 \%, \mathrm{n}=52)$. Out of the 1224 clinical cases, $110(9.06 \%)$ cases were diagnosed in fracture with lameness. Prevalence were mostly registered in rainy season $38.18 \%(n=42)$ followed by summer $(33.63 \%)$, autumn $(17.27 \%)$ and winter season $(10.90 \%, \mathrm{n}=12)$.

In this investigation, the prevalence of lymphadenitis was recorded at $6.59 \% \quad(n=$ 80/1224) in Muktagacha. Lymphadenitis in goats was mostly seen in summer season $43.75 \%(n=35 / 80)$ than all other seasons, as presented in Table 2. Analysis of $9(0.75 \%)$ clinical cases of gangrenous mastitis, the highest prevalence was found in the summer season $(44.11 \%)$ followed by autumn $(33.33 \%)$ and rainy as well as winter season $(11.12 \%)$.

Table 2. Prevalence and temporal distribution of surgical affections in goats at Upazila Veteinary Hospital, Muktagacha, Mymensingh $(\mathrm{n}=1224)$

\begin{tabular}{|lccccc|}
\hline \multicolumn{1}{c}{$\begin{array}{c}\text { Surgical } \\
\text { affections }\end{array}$} & $\begin{array}{c}\text { Number and } \\
\text { prevalence of } \\
\text { individual surgical } \\
\text { cases }\end{array}$ & Summer & Rainy & Autumn & Winter \\
\hline Wounds & $374(30.83 \%)$ & $112(29.94 \%)$ & $147(39.30 \%)$ & $61(16.31 \%)$ & $54(14.43 \%)$ \\
\hline Gid & $280(23.08 \%)$ & $54(19.28 \%)$ & $112(40.00 \%)$ & $68(24.28 \%)$ & $46(16.42 \%)$ \\
\hline Urolithiasis & $206(19.98 \%)$ & $27(13.10 \%)$ & $62(30.09 \%)$ & $39(18.93 \%)$ & $78(37.86 \%)$ \\
\hline Bloat & $120(9.89 \%)$ & $14(11.66 \%)$ & $39(32.50 \%)$ & $52(43.33 \%)$ & $15(12.50 \%)$ \\
\hline Fracture & $110(9.06 \%)$ & $37(33.63 \%)$ & $42(38.18 \%)$ & $19(17.27 \%)$ & $12(10.90 \%)$ \\
\hline Lymphadenitis & $80(6.59 \%)$ & $35(43.75 \%)$ & $15(18.75 \%)$ & $11(13.75 \%)$ & $19(23.76 \%)$ \\
\hline Tumor & $45(3.70 \%)$ & $18(40.00 \%)$ & $15(33.33 \%)$ & $5(11.11 \%)$ & $7(15.55 \%)$ \\
\hline $\begin{array}{l}\text { Gangrenous } \\
\text { mastitis }\end{array}$ & $9(0.75 \%)$ & $4(44.11 \%)$ & $1(11.12 \%)$ & $3(33.33 \%)$ & $1(11.12 \%)$ \\
\hline Total & $\mathbf{1 2 2 4}$ & $\mathbf{3 0 1}(\mathbf{2 4 . 6 0 \% )}$ & $\mathbf{4 3 3 ( 3 5 . 3 8 \% )}$ & $\mathbf{2 5 8 ( 2 1 . 0 7 \% )}$ & $\mathbf{2 3 2}(\mathbf{1 8 . 9 5 \% )}$ \\
\hline
\end{tabular}


We have documented the prevalence and seasonal influences of surgical diseases and disorders in Trishal Upazila. Data have been retrieved from Upazila Veterinary Hospital and illustrated in Table 3. A total of 361 (28.88\%) cases of different types of wounds were recorded in goats in Trishal Upazila. The wounds were most prevalent in rainy season (37.67\%, $\mathrm{n}=136)$, followed by summer $(29.63 \%, \mathrm{n}=107)$, autumn $(16.89 \%, \mathrm{n}=61)$ and winter season $(15.78 \%, \mathrm{n}=57)$.

Out of the 1240 surgical cases recorded here, $295(23.60 \%)$ cases were accounted as gid disease. In this locality, gid was mostly found in the rainy season $(40.33 \%)$ followed by in autumn (24.40\%), summer (17.96\%), and lowest prevalence was registered in the winter season $(n=51,17.28 \%)$.

Analysis of the data revealed 215 (17.20\%) cases of urolithiasis which were mostly observed in winter season $(36.74 \%, \mathrm{n}=79)$ followed by rainy $(28.37 \%, \mathrm{n}=61)$, autumn
$(21.39 \%, \mathrm{n}=46)$ and summer season $(13.48 \%$, $\mathrm{n}=29)$. In this investigation, $114(9.12 \%)$ cases were recorded as bloat, and mostly it has been observed in the autumn season $(43.85 \%)$ as shown in Table 3. In small ruminants, the fracture is most common due to either automobile accidents or excessive trauma. Out of 1240 cases, $112(8.96 \%)$ patients were documented for fracture. The fractures were mostly found in rainy season $42.85 \%(n=48)$ followed by summer (32.14\%), autumn $(16.07 \%)$ and winter season $(8.92 \%, \mathrm{n}=10)$ seen in Table 3. Lymphadenitis, a very important disease having clinical significance in goats, was accounted as high as $6.88 \%(n=86 / 1240)$ in this Upazila. We found the lymphadenitis most prevalent in summer season $40.69 \%$ ( $n=$ 35 ) and least in autumn 12 (13.95\%). Around $0.80 \%$ of gangrenous mastitis was documented in this investigation, where the highest prevalence was observed during the summer season $(40.00 \%, n=4)$ seen in Table 3 .

Table 3. Prevalence and temporal distribution of different surgical affections in goats in Upazila Veterinary Hospital, Trishal, Mymensingh $(n=1240)$

\begin{tabular}{|lccccc|}
\hline \multicolumn{1}{c}{$\begin{array}{c}\text { Surgical } \\
\text { affections }\end{array}$} & $\begin{array}{c}\text { Number and } \\
\text { prevalence of } \\
\text { individual surgical } \\
\text { cases }\end{array}$ & Summer & Rainy & Autumn & Winter \\
\hline Wounds & $361(28.88 \%)$ & $107(29.63 \%)$ & $136(37.67 \%)$ & $61(16.89 \%)$ & $57(15.78 \%)$ \\
\hline Gid & $295(23.60 \%)$ & $53(17.96 \%)$ & $119(40.33 \%)$ & $72(24.40 \%)$ & $51(17.28 \%)$ \\
\hline Urolithiasis & $215(17.20 \%)$ & $29(13.48 \%)$ & $61(28.37 \%)$ & $46(21.39 \%)$ & $79(36.74 \%)$ \\
\hline Bloat & $114(9.12 \%)$ & $12(10.52 \%)$ & $39(34.21 \%)$ & $50(43.85 \%)$ & $13(11.40 \%)$ \\
\hline Fracture & $112(8.96 \%)$ & $36(32.14 \%)$ & $48(42.85 \%)$ & $18(16.07 \%)$ & $10(8.92 \%)$ \\
\hline Lymphadenitis & $86(6.88 \%)$ & $35(40.69 \%)$ & $16(18.60 \%)$ & $12(13.95 \%)$ & $23(26.75 \%)$ \\
\hline Tumor & $47(3.76 \%)$ & $10(21.27 \%)$ & $13(27.65 \%)$ & $18(38.29 \%)$ & $6(12.76 \%)$ \\
\hline $\begin{array}{l}\text { Gangrenous } \\
\text { mastitis }\end{array}$ & $10(0.80 \%)$ & $4(40.00 \%)$ & $3(30.00 \%)$ & $2(20.00 \%)$ & $1(10.00 \%)$ \\
\hline Total & $\mathbf{1 2 4 0}$ & $\mathbf{2 8 6 ( 2 3 . 0 6 \% )}$ & $\mathbf{4 3 5}(\mathbf{3 5 . 0 9 \%})$ & $\mathbf{2 7 9 ( 2 2 . 5 0 \% )}$ & $\mathbf{2 4 0}(\mathbf{1 9 . 3 5 \% )}$ \\
\hline
\end{tabular}

\section{DISCUSSION}

Mymensingh, one of the oldest districts in Bangladesh, is known for its livestock resources in the country. The management practices of animals and geo-climatic conditions of the city are favourable for the occurrence of various diseases (Alam and Rahman, 2012). It has been proved that the prevalence of infectious or surgical diseases may vary according to age, sex, types, and season (Talukder et al., 2005; Hoda et al., 2018; Jaman et al., 2018). The present study was undertaken to find out the prevalence of surgical affections in goats in the 
South-west region of Mymensingh district. We observed a similar pattern of prevalence of all the recorded surgical diseases in all three Upazilas. This could be due to having similar geo-climatic conditions and husbandry practices as these regions are neighboring to each other.

Wounds, either infectious or non-infectious, are the most common problem in goats in Bangladesh (Tamanna et al., 2020) and, in most cases, if untreated for a longer period, may lead to myiasis (Miah et al., 2017). In the present study, we have retrieved a remarkable figure of wounds in the study areas $(30.54 \%, 30.83 \%$, and $28.88 \%$ in Fulbaria, Muktagacha, and Trishal, respectively). The incidence of wound affections is higher in rainy than the other seasons. Our report differed from an early report where wound infestation leading to myiasis was frequently observed from March to June, i.e., in the summer season (Juyena et al., 2013). However, research says myiasis is limited to the summer months in temperate zones, but may occur all the year-round in the tropics. During the summer season, when the temperature is warmer wound is reached full closure within a few weeks in contrast to winter and all other seasons (Vasquez, 2015).

In this study, it was observed that in the rainy season, the prevalence of gid was higher than the other period of the year. Alam et al. (2007) reported summer (48\%) followed by rainy $(30 \%)$ as the critical seasons for surgical gid occurrences, which contrasted to our findings. We speculate that in the rainy season, parasites become abundant on newly grown grasses and the animals easily become infected when they swallow green grass. Due to the geoclimatic situation and husbandry practices, our findings are different from the previous reporters.

Clinically 627 cases of urolithiasis, the highest incidence of urolithiasis, were recorded in winter season $37.86 \%$. This is similar to our previous findings conducted at Veterinary
Teaching Hospital (VTH) where urolithiasis was much higher in winter compared to other seasons (Sarker et al., 2020). Radostitis et al., (2000) reported that season had a significant effect upon the occurrence of urolithiasis. The occurrence of urolithiasis in feedlot animals in peak winter may be due to the decreased water intake and deficiency of vitamin- A arising from the lesser availability of green fodder. Sourcie et al., (1996) reported that urolithiasis was significantly higher in the summer season compared to winter, autumn, and rainy, which contrasted to our results. This may be partly attributable to higher ambient temperature during the summer season.

Most of the fractures in goats were caused by automobile accidents or massive trauma due to accidental falling/jumping and abuse/hitting (Mohiuddin et al., 2018). In our study, the highest incidence of fracture was recorded in the rainy season compared to all other seasons. In the rainy season, the surroundings become slippery, which acts as an inciting cause of the fracture.

Caseous lymphadenitis caused by Corynebacterium pseudotuberculosis is a common disease of goats that causes abscesses at the lymph nodes and results in poor production, weight loss, and death. Due to the chronic and generally subclinical nature of the infection, control is difficult, and prevalence in animals and herds is high. It affects mainly sheep and goats, though it can also infect cattle and horses, and rarely, humans; thus, it is considered an occupational zoonosis (de Sá Guimarães et al., 2011). In this study, lymphadenitis was documented as $6.48 \%$, $6.59 \%$, and $6.88 \%$ in Fulbaria, Muktagacha, and Trishal, respectively. The disease was frequently observed in animals above one year of age and is mostly found in males than females (data not shown). The highest incidence was found in the summer season. We surmise that in the summer season, animals are mostly injured, and the possible way for the entry of 
bacteria in the body is through the injured skin and mucous membrane.

Gangrenous mastitis in goats is a serious clinical inflammatory process involving the mammary gland. The disease is transmitted by ascending through the teat canal with agents from the environment, animal, or from milking process (Ribeiro et al., 2007). In our study, the disease was frequently noticed during summer season than all other seasons. Seasonal effects have also been reported for the incidence rate of clinical mastitis with the highest for streptococci and coliforms in the summer months (Makovec and Ruegg, 2003), which agreed to our findings. Because of the epidemiology of each pathogen is unique. Summer humidity and temperature increase coliform count in bedding material, resulting in increased coliform mastitis (Erskine et al., 1988). Seasonal differences were largest for Streptococcus uberis, followed by Streptococcus dysgalactiae and smallest for Escherichia coli in herds that kept animals inside only at night during the summer.

\section{CONCLUSIONS}

Our study reveals that surgical affections are very common in goats in Mymensingh and are remarkably influenced by seasons round the year having diverse distribution patterns. Rainfall, temperature, and relative humidity may influence the occurrence of these diseases and disorders. The high prevalence of surgical cases prevailing in goats in Mymensingh requires serious attention to minimize the effect of the problem.

\section{ACKNOWLEDGMENTS}

We thank Upazila Livestock Officer of Trishal, Fulpur, and Muktagacha for their cordial help in collecting retrospective data.

\section{Conflict of interest}

Authors have no conflicts of interest to declare.

\section{REFERENCES}

Abed, R., Acosta, A. (2018). Assessing Livestock Total Factor Productivity: A Malmquist Index Approach. African journal of agricultural research, 13, 297306. DOI: http://dx.doi.org/10.22004/ag.econ.284984

Alam, M.M., Rahman, M. (2012). A three years retrospective study on the nature and cause of ocular dermoids in cross-bred calves. Open Veterinary Journal, 2(1), 10-14. https://www.ncbi.nlm.nih.gov/pubmed/26623284

Alam, M.M., Hossain, M.A., Mohammed, Y. (2005). Effects of plasma with minerals and vitamin on various haematobiochemical parameters of calves. Bangladesh Veterinary Journal, 8, 15-24.

Alam, M.M., Anisuzzaman, Saha, D. (2007). Clinical investigation of neural and extraneural coenuriasis in Black Bengal goat. Journal of Bangladesh Society for Agricultural Science and Technology, 4, 169-172.

de Sá Guimarães, A., do Carmo, F.B., Pauletti, R.B., Seyffert, N., Ribeiro, D., Lage, A.P., Heinemann, M.B., Miyoshi, A., Azevedo, V., Gouveia, A.M.G. (2011). Caseous lymphadenitis: epidemiology, diagnosis, and control. The IIOAB Journal, 2, 33-43.

DLS. (2019). Livestock economy at a glance 2018-2019.

Erskine, R. J., Eberhart, R.J., Hutchinson, L.J., Spencer S.B., Campbell, M.A. (1988). Incidence and types of clinical mastitis in dairy herds with high and low somatic cell counts. American Veterinary Medical Association, 192, 761-765.

Hoda, N., Karim, M.R., Mishra, P., Shihab, M.M., Jaman, M.M., Alam, M.R., Alam, M.M. (2018). Occurrence of Schistosomus reflexus in neonatal bovine calves in certain areas of Bangladesh: a retrospective study. Bangladesh Veterinary Journal, 52(1-4), 39-45. https://doi.org/10.32856/bvj-2018.05

Hossain, M.J., Ahmed, J.U., Alam, M.M. (2014). Reproductive performance of Black Bengal goat under semi-intensive and extensive condition at rural areas in Bangladesh. Journal of Advanced Veterinary and Animal Research, 1, 196-200. Doi: http://dx.doi.org/10.5455/javar.2014.a37

Islam, M.Z., Runa, R.A., Alam, M.M. (2020). Prevalence and risk factors analysis of bovine foot diseases in certain milk pocket areas of Sirajganj district, Bangladesh. Veterinary Science: Research and Reviews. Veterinary Sciences: Research and $\begin{array}{llll}\text { Reviews, } & 6 & \text { (2), } & 73-79 .\end{array}$ http://dx.doi.org/10.17582/journal.vsrr/2020/6.2.73.79

Jaman, M.M., Mishra, P., Rahman, M., Alam, M.M. (2018). Clinical and laboratory investigation on the recurrence of the umbilical hernia after herniorrhaphy in bovine calves. Journal of the Bangladesh Agricultural University, 16(3), 464-470. https://doi.org/10.3329/jbau.v16i3.39418 
Juyena, N.S., Tapon, M.A.H., Ferdousy, R.N., Paul, S., Alam, M.M. (2013). A retrospective study on occurrence of myiasis in ruminants. Progressive Agriculture, 24, 101- 106. Doi: https://doi.org/10.3329/pa.v24i1-2.19110

Makovec, J.A., Ruegg, P.L. (2003). Results of milk samples submitted for microbiological examination in Wisconsin from 1994 to 2001. Journal of Dairy Science, $86, \quad 3466-3472$. Doi: https://doi.org/10.3168/jds.S0022-0302(03)73951-4

Miah, M.A.H., Hasan, M., Sarker, Y.A., Alam, M.M., Juyena, N.S. (2017). Clinical evaluation of ethanolic extract of curcumin (Curcuma longa) on wound healing in Black Bengal goats. Journal of Advanced Veterinary and Animal Research, 4, 181-186. Doi: http://doi.org/10.5455/javar.2017.d209

Mohiuddin, M., Hasan, M.M., Shohag, M., Ferdousy, R.N., Alam, M.M., Juyena, N.S. (2018). Surgical management of limb fractures in calves and goats. Bangladesh Veterinary Journal, 52(1-4), 46-56. Doi: https://doi.org/10.32856/bvj-2018.06

Nelson, J.R., Demas, E.G., Klein, L.S., Kriegsfeld, J.L. (2002). Seasonal patterns of stress, immune function and disease. 1st ed.Cambridge University Press, Cambridge, UK.

Omoike, A. (2006). Prevalence of disease among sheep and goats in Edo State, Nigeria. Journal of Agriculture and Social Research, 6(2): 23-31. Doi: $\underline{10.4314 / \text { jasr.v6i2.47013 }}$

Radostits, O.M., Blood, D.C., Gay, C.C., Hinchcliff, K.W. (2000). Urinary System. In: "Veterinary Medicine: A textbook of the diseases of cattle, sheep, pigs, goats and horses", 1877, Bailliere Tindall, London.

Rassel, M.G.R., Mishra, P., Rahman, M., Alam, M.M. (2020). Exploring bacterial pathogens and risk factors associated with the occurrence of navel ill in calves. Journal of Istanbul Veterinary Sciences, 4, 37-42. Doi: $\quad$ http://dx.doi.org/10.30704/http-www-jivsnet.722788.

Ribeiro, M.G., Lara G.H.B., Bicudo, S.D., Souza, A.V.G., Salerno, T., Siqueira, A.K., Geraldo, J.S. (2007). An unusual gangrenous goat mastitis caused by Staphylococcus aureus, Clostridium perfringens and Escherichia coli co-infection. Arquivo Brasileiro de Medicina Veterinária e Zootecnia, 59, 810-812. DOI: https://doi.org/10.1590/S0102$\underline{09352007000300037}$

Sarker, D., Akter, M.A., Rahman, M.S., Yesmin, N., Alam, M.M. (2020). Clinicopathological Consequences of Urinary Retention due to Urolithiasis in Indigenous Goats. PSM Veterinary Research, 5(2): 28-37.
Shoriotullah, M., Hasan, M., Haider, M.G., Miah, M.A.H., Mallick, S., Biswas, D.S., Alam, M.R., Hashim, M.A. (2017). Lymphadenitis and Its Remedy in Goats of Certain Areas of Kushtia District in Bangladesh. Bangladesh Veterinary Medical Record, 3(1\&2), 1-6.

Sourcie, J.M., Coates, R.J., McClellan, W. (1996). Relationship between geographic variability in kidney stones prevalence and risk factors for stones. American Journal of Epidemiology, 143, 491- 495.

Tamanna, S.J., Shihab, M.M., Akter, M.A., Rahman, M., Alam, M.M. (2020). Therapeutic potentialities of green tea (Camellia sinensis) and aloe vera (Aloe barbadensis) on Staphylococcus aureus induced septic wound in goats. Journal of Bangladesh Agricultural University, 18, 1, 105-110. DOI: https://doi.org/10.5455/JBAU.94746

Talukdar, M.M.A.A., Alam, M.M., Mohammed, Y., Mattra, C., Hossain, M.A. (2005). Claw affections of dairy cows in an organized dairy farm. Bangladesh Journal of Veterinary Medicine, 3(2), 110-113. Doi: https://doi.org/10.3329/bjvm.v3i2.11337.

Vasquez, A.C., John, R., Caldwell, Paul, A., Faure. (2015). Seasonal and reproductive effects on wound healing in the flight membranes of captive big brown bats. Biology Open, 4, 95-103. Doi: https://doi.org/10.1242/bio.201410264 . 